\title{
Structural determinants of GBV against refugee youth: Advancing critical theoretical perspectives
}

\author{
Negar Alamdar, York University
}

\begin{abstract}
The scholarship on gender-based violence (GBV) against refugee youth has succeeded in highlighting the significance of micro social psychological or situational analyses. Missing, however, are analyses that incorporate structural approaches, especially as informed by critical feminist and critical race theories. This review not only suggests ways in which structural analyses may proceed by further recommending the conceptual utility of integration and dislocation as key concepts in refugee studies, GBV and analyses of youth. These concepts mediate the relationships between two fundamental and prevailing units in the social theorizing - micro and macro-analyses. By incorporating more holistic, relational and critical foci regarding systems of domination (misogyny, racism, youth discrimination, homophobia) within the political economy and culture and their embedded institutions, more systemic and long term remedies are recommended.
\end{abstract}

Keywords: integration, dislocation, gender- based violence, refugee youth

Abstrait: L'érudition sur la violence basée sur le genre (VGB) à l'encontre des jeunes réfugiés a réussi à mettre en évidence l'importance des analyses micro-psychologiques ou situationnelles. Cependant, il manque des analyses qui intègrent des approches structurelles, en particulier sur la base du critique féministe et des théories raciales critiques. Cette revue suggère non seulement des façons dont les analyses structurelles peuvent procéder en recommandant davantage l'utilité conceptuelle de l'intégration et de la dislocation en tant que concepts clés dans les études sur les réfugiés, la VBG et les analyses des jeunes. Ces concepts médiatisent les relations entre deux unités fondamentales et dominantes dans la théorisation sociale - les micro et macro-analyses. En incorporant des concentrations plus holistiques, relationnelles et critiques concernant les systèmes de domination (misogynie, racisme, discrimination des jeunes, homophobie) dans l'économie et la culture politiques et leurs institutions intégrées, des remèdes plus systémiques et à long terme sont recommandés.

Resumen: La investigación sobre violencia de género contra jóvenes refugiados subraya la relevancia de los análisis situacionales o desde la psicología social a nivel micro. Algo que escapa en este tipo de investigaciones la incorporación de enfoques estructurales, especialmente aquellos basados en el feminismo crítico y en teorías críticas de raza. En este artículo sugerimos la incorporación de conceptos útiles para el análisis del tema, incluyendo el concepto de integración y el de dislocación, como conceptos claves para los estudios sobre refugiados, violencia de género y juventud. Estos conceptos median la interrelación entre los análisis micro y macro. Sugerimos recomendaciones de tipo sistémico y a largo plazo, basadas en aproximaciones holísticas y críticas que aluden a sistemas de dominación (misoginia, racismo, discriminación, homofobia) dentro de la económica política, cultura e instituciones donde éstos se insertan.

\section{Introduction: Conceptual contexts}

The scholarship on gender-based violence (GBV) directed against refugee youth is informed by a rich empirical history drawing from an array of theoretical perspectives that highlight situational, sociopsychological and micro dimensions. Often overlooked in etiological studies of GBV are structural or systemic explanations. Macro accounts maintain that GBV is structurally situated and efforts to combat this insidious practice warrant more macro, systemwide and long term solutions. The omission in mainstream empirical inquiries may be due to a reluctance to move beyond the realm of the situated self. I suggest that a more coordinated and coherent analysis of the GBV's structural embeddedness (Crocco,2001; Walby \& Towers, 2017) is required.

Moreover, I argue that structural features of GBV are overshadowed by processual or micro analyses which 
consistently understate such structures as the political economy and the structural foundations of misogyny, racism and youth discrimination. The voluminous scholarship from leading feminists, critical theorists, critical race analysts and progressive human rights activists continues to urge the incorporation of structured intersectionalities of violence (Connell, 1998; Walby, 2005; Connell, 2011).

Given the ongoing debate in the social sciences regarding the relationship of the self (micro) and the social structure (the macro), I ask, how does one avoid this "either/ or" binary and move towards a more holistic appreciation of both the self and the social? One such approach is to incorporate the idea of mediation, a basic concept in theorizing and in conducting empirical research. Mediation is the practice of taking the contributions of both macroand micro analyses in an effort to provide a more comprehensive explanation. Van Hear (1998) notes that in addressing micro-macro linkages one should "deal simultaneously with these levels from individual to macro though integrative strategies". That is, one ought to consider explanations from both these levels of analysis (Visano, 2015). Mediation refers to those ideas that come between, ideas that mitigate, intervene in the relationship between self and structure.

In relation to GBV against refugee youth, what then mediates the relationships between agency (self, interactions, situations) and structure (systems, history and cultures of capitalism, misogyny, racism, ageism, homophobia)? In this paper, I maintain that the idea of relationality (the relatedness of units of analysis-micro, mezzo, macro) provides a formidable substantive and theoretical site for: investigating issues of gender- based violence; unravelling the connectedness of concepts and applied practices; and, questioning dominant modes of thinking about GBV. Specifically, in this paper, I would like to provide a long overdue appreciation of the agency (self) process (structure) linkages as mediated by the concepts of dislocation and integration of refugee youth afflicted with gender- based violence. Dislocation and integration refer to levels of attachment to social values and social institutions. The concepts of youth dislocation and integration are refreshingly interconnected and appropriately counter-hegemonic in the traditions of critical feminist and critical race scholarship. These two concepts enjoy a rich history of sociological scholarship (Durkheim, 1965; Giddens, 1976).

\section{Intersectionalities and structural violence}

Patricia Hill Collins (2000) cautions that there is an overarching system of ideas that governs the logic and structure of social, political and economic domination. Structures of domination become formulated around relationships of difference (gender, race, age, ethnicity, sexual orientation, ability, nationality and creed) to construct relationships of power and domination (racism, sexism, classism, ableism, homophobia, ageism, migration status, etc.). Feminist perspectives, judged to be insufficiently represented and accommodated within mainstream disciplines (Oakley, 1981; Simpson, 1989). These theoretical perspectives contribute to a profound theoretical awareness of the past and present constructions of women's experiences (Keohane and Gelpi, 1982). Eichler (1985) explains that feminist approaches provide a critical attitude towards research, replacing its inherent bias with an intersectional and critical standpoint. Harding $(1987,1991)$ argues that there is evidence of repression in scientific "objective science" (knowledge) in the name of theories and methods that speak strictly in a male voice. The strength of feminist research then is its attempt to address the lingering questions concerning the role of the dominant culture in creating conditions that shape the collection and analysis of empirical data.

Similarly, critical race theoretical approaches provide a critique of characteristics of the Canadian culture and class inequalities in order to improve social conditions, rather than reproduce existing structures. By drawing attention to the treatment GBV of refugee youth, critical race theory invites interdisciplinary orientations that challenge the more single-minded dominant ideologies and encourage a more authentic 
commitment to social justice. In theorizing about this violence, critical theory highlights the contexts and consequences of the culture of racism that reproduces the pernicious white privilege (Galtung,1990). Clearly, race and gender cannot be treated separately (Moghissi, 1994) given that the dominant culture penalizes "women of colour". In reference to $\mathrm{GBV}$, race and gender have played significant roles in the responses of the legal system and in the available support services (Couto \& Visano, 2012). I would add that is important to highlight the importance of understanding how intersectional factors contribute to the existing vulnerabilities of refugee youth, their challenges with their self-agency and their responses to the impact of the systemic structures.

\section{Structural embeddedness and the institutionalizing of structures: Theoretical refinements}

The foundations of competing interests and complementing intersections and their linkages are needed for a more comprehensive analysis of GBV among refugee youth. The foundations include deeply rooted misogyny, well entrenched racism and traditions of anti- youth bias.

Accordingly, structures of law, history, political economy, media and culture impact on how everyday institutions (Bourdieu, 2011) deal with refugee youth. From the family to service providing agencies, values are reflective of tradition, culture and the political economy, all of which need to be incorporated theoretically in addressing the determinants of gender- based violence. An understanding of GBV is not related solely to structures of thinking but also benefits from experimental and experiential examination. GBV is not related solely to social psychology but to the racist discrimination, language barriers, lack of educational and employment opportunities and poverty. Indeed, it is important to consider the existential experiences of refugee youths which render them vulnerable to victimization (Totten, 2000) and further dislocation.

Institutions dealing with gendered refugee youth defer to structures of dominance (Sivan, Koch, Baier
\& Adiga,1999). This is most acute with the health delivery service and barriers that prevent refugee youth from receiving mental health services (Ellis, Miller, Baldwin \& Abdi, 2011). For instance, Berthold (2000) documents war traumas and associated PTSD, community violence and the absence of well-being among Khmer refugee.

I would like to argue given the children's rights discourse, academics, politicians and service providers need to work collaboratively to respect and enhance the voices of victims who continue to direct attention to much ignored structural factors such as poverty, health determinants, racism and misogyny (Barbulescu \& Grugel, 2016; Otto, 2019; Lems 2019). Witness, for example, how the research on sexual exploitation of children and human trafficking have paid little attention to much needed structural analyses. Empirical studies have succeeded in making the argument empirically that research on refugee youth has been characterized by contradictory policies and services that impact negatively on the well-being of these youths (Bierwirth, 2005; Bhabha 2008; Fong \& Cardoso, 2010; Freedman, 2016; Lems, Oester \& Strasser, 2019)

\section{Conclusion: An agenda for future research}

A critical theoretical set of interrelated perspectives serves to complement situational, social psychological or institutional analyses. What emerges from such a critical inquiry of gender-based violence among refugee youths are the concepts of dislocation and integration. I highly recommend the importance of studying these two concepts together in order to understand the challenges facing refugees. Structural factors highlight both the dislocation and integration felt by this marginalized population who are "in" but not "of" the host country. My paper suggest that these two concepts introduce notions of nearness and remoteness socially, politically, physically and psychologically that warrant further research. To be able to fully understand GBV, we have to conceptually understand the importance of looking at agency and structure in relation to dislocation and integration. An agenda for future research and policy implications 
is a consideration of how refugee youth integrate their respective cultural traditional with western values and how institutions accommodate to their sense of location and belongingness. In other words, how do youths and institutions negotiate integration in light of structural barriers given multiple factors that influence refugee adolescent mental health (Filler, 2018:12)?

Interestingly, there have been recent scholarship that contributes immeasurably to implicating and incorporating systems approaches in examining resilience and power (Khanlou N, Bender A, Mill C, Vazquez L \& Rojas L, 2018). In my understanding, Dr. Khanlou's scholarly work further enhances an appreciation of dislocation and integration and its relation to agency and structure by using a different lens.

The concept of "structured agency", that is, the social self, assists in understanding GBV. The idea of structured agency incorporates youth values (intrinsic to being, emotions, unconscious, instincts) and imposed values (subcultural, institutional). Theoretical and more applied scholarship, past and present, will indicate how GBV is recognized and represented within the contexts of integration and as an outcome of the refugee migration process

Acknowledgements: The author wishes to acknowledge with heartfelt gratitude the ongoing mentorship, generous insights and relentless guidance provided by Professor Nazilla Khanlou, Research Chair of the Office of Women's Health in Mental Health. An inestimable appreciation is also extended to the Lillian Meighen Wright Post- Doctoral Fellowship for its constant support and encouragement.

\section{References}

Barbulescu, R, \& Grugel, J. (2016). Unaccompanied minors, migration control and human rights at the EU's southern border: the role and limits of civil society activism. Migration Studies, 4(2), 253-272.
Berthold, S. M. (2000). war traumas and community violence. Journal of Multicultural Social Work, 8 (1-2), 15-46.

Bhabha, J. (2008). Independent children, inconsistent adults: international child migration and the legal framework. Florence, Italy: UNICEF.

Bierwirth, C. (2005). The protection of refugee and asylum-seeking children, the convention on the rights of the child and the work of the committee on the rights of the child. Refugee Survey Quarterly, 24(2), 98-124.

Bourdieu, P. (2011). Reproduction in education, society, and culture. London, UK: Sage.

Carastathis, A, Kouri-Towe, N, Mahrhouse,G. \& Whitley, L. (2018). Introduction: Intersectional Feminist Interventions in the 'refugee crisis'. Refuge, 34(1), 315.

Connell, R. (2011). Gender and social justice: southern perspectives. South African Review of Sociology, 42(3), 103-115.

Connell, R. (1998). Gender and Power: Society, the Person and Sexual Politics Cambridge. London, UK: Polity Press.

Couto, N \& L. Visano (2012). Violated and Silenced. Toronto, ON: APF Publishers.

Crocco, M. S. (2001). The missing discourse about gender and sexuality in the social studies. Theory into Practice, 40(1), 65-71.

Durkheim, E. (1965). The Rules of the Sociological Method translated. New York, NY: Free Press.

Eichler, M. (1985). "And the Work Never Ends: Feminist Contributions." Canadian Review of Sociology and Anthropology, 22, 619-644.

Ellis, B. H, Miller, A, Heather Baldwin, H., \& Abdi, S., (2011). New directions in refugee youth mental health services: overcoming barriers to engagement. Journal of Child \& Adolescent Trauma , 4(1), 69-85.

Filler, T. (2018). Addressing Syrian refugee adolescents' mental health and wellbeing: Youth-informed policy implications. International Network on Youth Integration, 9 (1), 12-17.

Fong, R. \& Berger Cardoso, J. (2010). Child human trafficking victims: Challenges for the child welfare 
system. Evaluation and Program Planning, 33(3), 311-316.

Freedman, J. (2016) Sexual and gender-based violence against refugee women: a hidden aspect of the refugee "crisis". Reproductive Health Matters, 24(47), 18-26.

Galtung, J. (1990). Cultural violence. Journal of Peace Research, 27(3), 291-305.

Giddens, A. (1976). New Rules of Sociological Methods. New York, NY: Basic.

Harding, S. (1987). Feminism and methodology: social science issues. Bloomington, Indiana: Indiana University Press.

Harding, S. (1991). Whose science? whose knowledge? thinking from women's lives. Ithaca, New York: Cornell University Press.

Hill-Collins, P. (2000). Black feminist thought: knowledge, consciousness, and the politics of empowerment. New York, NY: Routledge.

Khanlou N, Bender A, Mill C, Vazquez LM \& Rojas L. (2018). Youth experiences of cultural identity and migration: A systems perspective. In S. Pashang, N. Khanlou \& J. Clarke (Eds), Today's youth and mental health: Hope, power, and resilience. Advances in Mental Health and Addiction (pp. 57-76). New York, NY: Springer.

Keohane, N. and B. Gelpi, (1982). Foreword. In N. Keohane, M. Rosaldo \& B. Gelpi (Eds.) Feminist theory: a critique of ideology (pp. 2-11). Chicago: University of Chicago Press.

Keygnaert, I. \& Guieu, A. (2015). What the eye does not see: a critical interpretive synthesis of European Union policies addressing sexual violence in vulnerable migrants. Reproductive Health Matters, $23,46$.

Lems, A., Oester, K. \& Strasser, S. (2019) Children of the crisis: ethnographic perspectives on unaccompanied refugee youth in and en route to Europe. Journal of Ethnic and Migration Studies, 2-17. DOI: 10.1080/1369183X.2019.1584697

Haideh, M. (1994). Populism and feminism in Iran. New York, NY: St Martin's Press.
Oakley, A. (1981). Interviewing Women: A Contradiction in Terms. In H. Roberts (Ed.), Doing feminist research (pp. 30-61). London: Routledge.

Otto, L. (2020). Children, adults or both? Negotiating adult minors and interests in a state care facility in Malta. Journal of Ethnic and Migration Studies, 46(2), 372-388.

Simpson, S. (1989). Feminist theory, crime and justice. Criminology, 27(4), 605-631.

Sivan, A. Koch,L., Baier, C. \& Adiga, M. (1999). Refugee youth at risk: a quest for rational policy. Children's Services, 2(3), 139-158.

Totten, D, M. (2000). Guys, gangs and girlfriend abuse. Peterborough, ON: Broadview Press.

High Commissioner for Human Rights. (1989). Convention on the rights of the child. Geneva, Switzerland: United Nations General Assembly.

Van Hear, Nicolas. (1998). New Diasporas: The mass exodus, dispersal and regrouping of migrant communities. Seattle, WA: University of Washington Press.

Visano, L. (2015). Dislocation as deracinated subjectivities: a case of refugee youths. In $\mathrm{M}$. Jacobs (ed) From geographical dislocation to social dislocation (pp. 143-179). oronto: APF Press.

Walby, S. (2005). Gender mainstreaming: productive tensions in theory and practice. State \& Society, 12(3),321-343.

Walby, S. \& Towers, J. (2017). Measuring violence to end violence: mainstreaming gender. Journal of Gender-Based Violence, 1(1), 11-31.

Corresponding author: Negar Alamdar, PhD, Lillian Meighen Wright Post- Doctoral Fellow, Office of Women's Health Research in Mental Health, Faculty of Health, York University. esmat@yorku.ca 